HUBERT WILK

Instytut Historii PAN

\title{
PRÓBA MODERNIZACJI POLSKIEGO \\ PRZEMYSŁU MASZYNOWEGO W DRUGIEJ POŁOWIE LAT 60. PRZYPADEK FIATA $125 \mathrm{P}$
}

\begin{abstract}
Tempo postępu technicznego narzuca nam życie, narzuca nam sytuacja, świat, w którym żyjemy.

Władysław Gomułka ${ }^{1}$
\end{abstract}

Zarys treści: Tekst dotyczy podjętej w latach 60 . XX w. próby zmodernizowania polskiego przemysłu maszynowego. Działania decydentów zostały przedstawione na przykładzie negocjacji i podpisania kontraktu licencyjnego na produkcję w FSO nowego samochodu fiata 125p. Zawarcie umowy z włoskim Fiatem i rozpoczęcie wytwarzania średniolitrażowej osobówki miało mieć pozytywny wpływ na strukturę eksportu przemysłu maszynowego.

The content outline: The paper focuses on the attempts of modernising the Polish machine industry in the 1960s. The undertakings of the decision-makers are illustrated through the case of negotiating and signing license contract for the production of new motor vehicle, Fiat 125p, by the FSO. The cooperation with the Italian automobile company Fiat and the production of a car with mid-sized engine was meant to positively influence the structure of the export sector of the machine industry.

Słowa kluczowe: PRL, przemysł motoryzacyjny, samochody, motoryzacja, duży fiat, lata $60 . \mathrm{XX} \mathrm{w}$.

Keywords: Polish People's Republic, automotive industry, cars, motorization, Fiat $125 \mathrm{p}$, the $1960 \mathrm{~s}$

${ }^{1}$ Przemówienie końcowe Władysława Gomutki podczas X Plenum Komitetu Centralnego PZPR w dniu 18 kwietnia 1962 r., w: X Plenum Komitetu Centralnego Polskiej Zjednoczonej Partii Robotniczej w dniach 16-18 IV 1962 r., Warszawa 1962, s. 547. 
Po październikowym przełomie społeczeństwo Polski coraz odważniej zaczynało domagać się dostępu do samochodów. Przez prasę przewinęła się bardzo interesująca dyskusja nad możliwym kształtem rozwoju powszechnej motoryzacji ${ }^{2}$. Niemal wszyscy zabierający w niej głos, zarówno eksperci, jak i zwykli szeregowi użytkownicy samochodów, byli zgodni co do jednego - tylko poprzez wprowadzenie do produkcji małego, taniego, łatwo dostępnego dla przeciętnego Kowalskiego samochodu osobowego uda się pchnąc polskie społeczeństwo na ścieżkę przyspieszonej motoryzacji. Jednak takie opinie nie robiły większego wrażenia na decydentach, praktycznie wcale niewyrażajaccych zainteresowania dokonaniem korekt $\mathrm{w}$ krajowym przemyśle produkujaccym dwa modele aut osobowych: warszawę i syrenę. Jednocześnie zdawano sobie sprawę, iż przestarzałe konstrukcje produkowane w Fabryce Samochodów Osobowych (FSO) na Żeraniu nie były w żaden sposób konkurencyjne na rynku międzynarodowym. Miało to duże znaczenie dla ograniczenia wpływów dewizowych z tytułu eksportu, bowiem poważna część krajowej produkcji motoryzacyjnej kierowana była na rynki zewnętrzne. Produkowana od 1951 r. warszawa była modelem przestarzałym i na dodatek bardzo kosztownym w produkcji. Jak zauważali specjaliści ze Zjednoczenia Przemysłu Motoryzacyjnego (ZPM) produkowane przez światowe firmy na przełomie lat pięćdziesiątych i sześćdziesiątych samochody cechował „wybitny komfort i wygoda jazdy oraz znakomite wykończenie”. Warszawa odbiegała zasadniczo od standardów światowych: „niewygodne siedzenia kierowcy, niewygoda pomieszczenia dla pasażerów, brak hydraulicznego przeniesienia ruchu sprzęgła, wymagający wielkich nacisków pedał hamulca, skłonność samochod[u] do poślizgów, [...] układ przełożeń przestarzały, niedostosowany do nowoczesnych wymogów jazdy" - oceniali eksperci Zjednoczenia ${ }^{3}$. Mimo swoich wielu wad, była istotnym elementem polskiego eksportu4. Dość powiedzieć, iż niemal 30\% produkcji tego pojazdu z lat 1954-1960 było kierowane za granicę, głównie do krajów należących do bloku oraz Afryki

${ }^{2}$ H. Wilk, Samochód dla Towarzysza Wiestawa. Dyskusje nad kierunkiem rozwoju motoryzacji indywidualnej $w$ Polsce 1955-1970, „Polska 1944/45-1989. Studia i Materiały", t. 11, 2013, s. 277-296.

${ }^{3}$ Archiwum Akt Nowych w Warszawie (dalej: AAN), Ministerstwo Przemysłu Ciężkiego (dalej: MPC), sygn. 37/167, Monografia i wstępne kierunki programu rekonstrukcji branży, Warszawa, listopad 1965, k. 25.

${ }^{4}$ AAN, Ministerstwo Handlu Zagranicznego (dalej: MHZ), sygn. 4/509, Protokół z rewizji dokumentalnej przeprowadzonej w Centrali Handlu Zagranicznego Przemysłu Motoryzacyjnego „Motoimport” w Warszawie [...], Warszawa, 10 X 1959, bp. 
i Azji ${ }^{5}$. Przeprowadzone na przełomie 1960 i 1961 r. na zlecenie Ministerstwa Przemysłu Ciężkiego (MPC) i Ministerstwa Handlu Zagranicznego (MHZ) przez Centralę Handlu Zagranicznego (CHZ) „Motoimport" badania opłacalności eksportu wykazały, iż w przypadku warszawy sprzedaż na rynki zagraniczne przynosiła straty już od 1958 r. W samym tylko 1959 r. każdy dolar uzyskany ze sprzedaży egzemplarza tego pojazdu kosztował 160 zł. Trudności w uzyskaniu lepszych wyników eksportu brały się przede wszystkim z faktu niskiego popytu na samochodu $\mathrm{w}$ typie warszaw na rynkach światowych oraz niskiej jakości sprzedawanego auta. Mimo tak niekorzystnych wyników postanowiono nadal prowadzić eksport, chcąc $\mathrm{w}$ ten sposób utrzymać produkcję żerańskiej fabryki oraz mimo wszystko zachować znaczne wpływy dewizowe ${ }^{6}$.

Niniejszy artykuł przedstawia próbę modernizacji polskiego przemysłu maszynowego podjęta w latach 60. ubiegłego wieku. Wówczas w najwyższych kręgach władzy pojawiły się głosy, iż jedynie diametralna zmiana w strukturze tej branży przemysłu da pozytywny impuls, który, mówiąc kolokwialnie, „pociagnie” cała gospodarkę w stronę szybszego i nowoczesnego rozwoju. Temat reform gospodarczych lat 60 . był juz przedmiotem badań historyków gospodarczych, przede wszystkim Janusza Kalińskiego ${ }^{7}$ i Łukasza Dwilewicza ${ }^{8}$, jednak w niniejszym tekście chciałbym skupić się na przemyśle motoryzacyjnym i zakupie licencji

${ }^{5}$ Zaznaczyć należy, iż w poszczególnych latach wielkość eksportu wahała się, osiagając najwyższy wskaźnik w 1954 i 1956 r., kiedy to zagranicę sprzedano 47\% całej produkcji; Opowieść o FSO. Historia tej warszawskiej fabryki, red. prow. i koncepcja całości Z. Boniecki, przy współpr. R. Gajewskiego, Warszawa 2010, s. 158-159.

${ }^{6}$ AAN, MHZ, sygn. 4/511, [Pismo informacyjne] dotyczy: kontroli przeprowadzonej w Biurze Motoryzacyjnym CHZ „Motoimport” w zakresie eksportu samochodów, Warszawa, 17 IV 1961, k. 7-9. Drugi z produkowanych na Żeraniu samochodów - syrena - sprzedawany był tylko na rynku polskim. Resort handlu zagranicznego postulował co prawda wprowadzenie tego modelu na rynki zagraniczne, ale pod warunkiem poprawy jego jakości i polepszenia konstrukcji. Jednak owa sugestia nie znalazła uznania w przygotowanym na lata 1961-1965 przez MPC w planie eksportu; tamże, k. 7. Z kolei wytwarzany niemal chałupniczo przez zakłady lotnicze w Mielcu mikrus de facto nie był w ogóle w tej kwestii brany pod uwagę. Zreszta w najwyższych kręgach władzy owa „produkcja uboczna” zakładów mieleckich była dość mocno krytykowana; zob.: J. Zabłocki, Dzienniki 1956-1965, t. 1, Warszawa 2008, s. 234.

7 Zob. np.: J. Kaliński, Gospodarka Polski w latach 1944-1989. Przemiany strukturalne, Warszawa 1995, s. 124-147.

${ }^{8}$ Ł. Dwilewicz, Reformy Bolestawa Jaszczuka i polityka gospodarcza ekipy gierkowskiej-zwrot i ciagtość, w: Dekada Gierka. Wnioski do obecnego okresu modernizacji Polski, Warszawa 2011. 
na produkcję fiata 125p. Podstawą źródłową są materiały archiwalne zgromadzone w Archiwum Akt Nowych (AAN).

Wspomniana na wstępie dyskusja nad kształtem polskiej motoryzacji jednoznacznie zakładała zakup zagranicznej licencji. W odróżnieniu bowiem od rozpoczęcia produkcji samochodu rodzimej konstrukcji nie było to $\mathrm{w}$ tak dużym stopniu obciażone niebezpieczeństwem porażki. Dodatkowo także oznaczało, przynajmniej w teorii, szybkie uruchomienie montażu gotowych pojazdów ${ }^{9}$. W lipcu 1957 r. Józef Cyrankiewicz wydał zarządzenie powołujące specjalną komisję, która zająć się miała opracowaniem zagadnień związanych z produkcja samochodu popularnego. Na jej czele stanął Eugeniusz Szyr. Będący efektem prac komisji raport pt. „Wnioski w sprawie uruchomienia produkcji samochodu popularnego" i warunki w nim przedstawione niemal w całości pokrywał się z tym, co proponowali specjaliści: popularna osobówka miała być czteroosobowa, w miarę oszczędna (spalajacca 8 litrów paliwa na $100 \mathrm{~km}$ ). Zakładano, iż docelowa produkcja, mająca wynieść 120 tys. sztuk rocznie, miała zaspokoić zarówno potrzeby krajowe, jak i eksportowe. Nowy pojazd miał być wytwarzany początkowo na Żeraniu, jednak planowana wielkość produkcji powodowała, iż zakładano budowę nowej fabryki. Wskazano nawet potencjalne lokalizacje: Warszawa, Lublin, Poznań lub Łódź. Komisja zalecała także oparcie produkcji na licencji. Sondowano nawet $\mathrm{w}$ tym celu rynki zagraniczne. Wstępne zainteresowanie interesami ze strona polska wyraziły m.in. firmy francuskie (Renault i Simca) oraz Fiat i brytyjski Triumph ${ }^{10}$. Jednak na luźnych rozmowach się skończyło, zaś opracowanie przygotowane przez komisję Szyra zostało w wyniku oporu najwyższych władz (przede wszystkim Władysława Gomułki) odrzucone ${ }^{11}$.

Argumentacja przedstawiona $\mathrm{w}$ raporcie nie przypadła do gustu ludziom z kręgów odpowiedzialnych za przemysł. Jeszcze na początku 1958 r. minister komunikacji Ryszard Strzelecki na pierwszym plenarnym zebraniu Rady Motoryzacyjnej o rozwoju motoryzacji indywidualnej mówił tak: „Wydaje się, że problem motoryzacji indywidualnej możemy rozwiązać jedynie poprzez uruchomienie i rozwinięcie własnej produkcji samochodów osobowych, odpowiadajacych cechami konstrukcyjnymi

9 A. Dłutek, Kooperacja polsko-włoska Fiat 126 - zakup licencji, Warszawa 1979, s. $5-6$.

10 AAN, Ministerstwo Komunikacji (dalej: MK), sygn. II/2, Protokół nr 7/P z posiedzenia Prezydium Rady Motoryzacyjnej odbytego dnia 28 IV [19]58, k. 417.

${ }^{11}$ Za przekazanie tych informacji dziękuję prof. Jerzemu Kochanowskiemu. 
i ceną specyfice naszego kraju"12. Kurtuazyjny ton wypowiedzi ministra był prawdopodobnie $\mathrm{w}$ dużej mierze podyktowany chęcią potrzymania pozytywnej atmosfery wokół ekipy rządzącej. Szybko bowiem retoryka zarówno $\mathrm{w}$ tonie, jak i w przedmiocie wypowiedzi wróciła na stare tory. Strzelecki pod koniec 1958 r. na kolejnym posiedzeniu Rady Motoryzacyjnej mówił: „[...] nie negując potrzeb w zakresie samochodu popularnego, sytuacja gospodarcza kraju nie pozwala na priorytetowe traktowanie jego produkcji przed szeregiem innych potrzeb społeczeństwa i rozwoju innych gałęzi przemysłu, które maja zasadniczy wpływ na harmonijny rozwój gospodarki narodowej" ${ }^{13}$. Wtórował mu minister przemysłu ciężkiego Kiejstut Żemajtis, który nie pozostawiał złudzeń co do kształtu najbliższych lat w motoryzacji osobowej, zapowiadając nawet, iż jakiekolwiek zmiany w polityce państwa względem motoryzacji indywidualnej nie będą możliwe aż do 1965 r. Jednocześnie jednak zostawił pewne światełko $\mathrm{w}$ tunelu. $\mathrm{W}$ tym czasie bowiem przedstawiciele MPC prowadzili z Czechosłowacją rozmowy o możliwości kooperacji przy produkcji samochodów osobowych. W przypadku niepowodzenia $\mathrm{w}$ negocjacjach $\mathrm{z}$ południowym sasiadem ministerstwo miało nawiązać rozmowy o nabyciu licencji, jednak przy założeniu, że nie będzie ona miała „charakteru "kolonialnego»"14. Obawiano się przede wszystkim, iż do czasu, aż polski przemysł będzie w stanie wykonywać całe samochody z części wyprodukowanych w Polsce, skazany zostanie wyłącznie na kosztowny import podzespołów od licencjodawcy ${ }^{15}$.

Zaznaczyć należy, iż członkowie Rady Motoryzacyjnej należeli do największych krytyków prowadzonej przez państwo polityki dotyczącej rozwoju motoryzacji. Raz po raz na jej posiedzeniach dochodziło do spięć z członkami rządu, konsekwentnie zapraszanymi na obrady. Tak było choćby pod koniec kwietnia 1960 r., kiedy to doszło do ostrej wymiany zdań pomiędzy wiceministrem Antonim Czechowiczem a reprezentującym Radę Motoryzacyjną Wiktorem Sudrą z Politechniki Warszawskiej. Ten pierwszy był zdania, iż produkcja popularnego samochodu osobowego nie była dla gospodarki priorytetem, zaś ewentualna produkcja miała opierać się na kooperacji z Czechosłowacja, nad którą

12 AAN, MK, Przemówienie Ministra Komunikacji Ryszarda Strzeleckiego na I Plenarnym Zebraniu Rady Motoryzacyjnej, [3 I 1958], k. 18.

${ }_{13}$ Tamże, Protokół nr 5 z zebrania plenarnego Rady Motoryzacyjnej w dniu 12 XII 1958, k. 66.

${ }^{14}$ Tamże, Protokół nr 1/P z posiedzenia Prezydium Rady Motoryzacyjnej odbytego w dniu 2 I 1959, k. 451.

15 Tamże, Protokół nr 7/P z posiedzenia Prezydium Rady Motoryzacyjnej odbytego dnia 28 IV [19]58, k. 416. 
wówczas poważnie się zastanawiano. Czechowicz zaznaczył także, iż $\mathrm{w}$ przypadku niepowodzenia $\mathrm{w}$ rozmowach $\mathrm{z}$ południowym sasiadem należało dokonać gruntownej modernizacji syreny, co nie będzie wymagało budowy nowej, wielkiej wytwórni. Sudra pozwolił sobie na krytykę swego przedmówcy, twierdząc, iż przy podejmowaniu decyzji w sprawach dotyczących przemysłu motoryzacyjnego nie była wcale brana pod uwagę opinia rady. Miał tutaj na myśli kwestię samochodu popularnego (rada była za produkcją takiej konstrukcji), modernizacji warszawy (rada uważała modernizację za bezcelowa) i wstrzymania produkcji mikrusa (rada chciała jej utrzymania) ${ }^{16}$.

Wspomniany już tutaj kilkakrotnie pomysł kooperacyjnej produkcji motoryzacyjnej wspólnie z Czechosłowacja przybrał dość realny kształt w 1959 r. Już wcześniej Kreml poprzez Radę Wzajemnej Pomocy Gospodarczej naciskał na pozostałe państwa bloku, aby te opracowywały wspólne plany rozwoju poszczególnych gałęzi produkcji oraz prowadziły inwestycje z udziałem co najmniej dwóch krajów ${ }^{17}$. W wytycznych rozwoju gospodarki narodowej w latach 1959-1965 zawartych w uchwale zamykającej III Zjazd PZPR znalazł się nawet ustęp nakazujący uwzględnienie przy planowaniu produkcji przemysłowej specjalizacji i kooperacji w ramach obozu socjalistycznego ${ }^{18}$. Delegacja czechosłowacka, która przybyła do Warszawy w 1959 r., składała się z przedstawicieli Ministerstwa Ogólnego Budownictwa Maszynowego. $\mathrm{Na}$ spotkaniu z przedstawicielami MPC uznano za celowe rozpatrzenie warunków niezbędnych dla rozpoczęcia wspólnej i masowej produkcji samochodu osobowego o pojemności silnika w granicach $1000 \mathrm{~cm}^{3}$. Zakładano, iż w perspektywie dekady w każdym z krajów powstanie montownia pojazdów oraz nastapi podział produkcji podzespołów, niezbędny do uzyskania niskich kosztów własnych samochodu oraz oszczędności w nakładach inwestycyjnych. Postanowiono także poinformować o możliwościach współpracy odpowiednie ministerstwa w Niemieckiej Republice Demokratycznej ${ }^{19}$. W kolejnych latach nadal

${ }^{16}$ Tamże, Protokół nr 2/60 z posiedzenia Prezydium Rady Motoryzacyjnej odbytego w dniu 26 IV 1960, k. 522.

17 R. Skobelski, Polityka PRL wobec państw socjalistycznych w latach 1956-1970. Wspótpraca - napięcia - konflikty, Poznań 2010, s. 211; zob. także przemówienie Piotra Jaroszewicza podczas III Zjazdu Polskiej Zjednoczonej Partii Robotniczej: III Zjazd Polskiej Zjednoczonej Partii Robotniczej. Stenogram. Warszawa 10 III-19 III 1959 r., Warszawa 1959, s. 430-433.

18 III Zjazd Polskiej Zjednoczonej Partii Robotniczej, s. 1092.

19 AAN, Komitet Współpracy Gospodarczej z Zagranica (dalej: KWGzZ), sygn. 20/54, Protokół z rozmów między delegacjami Ministerstwa Przemysłu Ciężkiego Polskiej Rzeczypospolitej Ludowej i Ministerstwa Ogólnego Budownictwa Maszynowego 
prowadzono rozmowy o wspólnej produkcji, już przy udziale przedstawicieli wschodnich Niemiec, jednak nie zakończyły się one podjęciem żadnych wiążących decyzji. Nadal miała być to produkcja niewielkiego samochodu popularnego. Trzy kraje miały wspólnie wytwarzać pół miliona sztuk pojazdów rocznie, bowiem tylko przy takiej wielkości produkcji możliwe było zorganizowanie nowoczesnej, zautomatyzowanej produkcji oraz szerokiej kooperacji pomiędzy krajami. Także w ten sposób możliwe było zmniejszenie nakładów inwestycyjnych do $30-40 \%{ }^{20}$. Nie da się ukryć, iż największym beneficjentem podjęcia ewentualnej współpracy w przemyśle motoryzacyjnym byłaby Polska ${ }^{21}$. Zyskałaby bowiem w ten sposób dostęp do technologii swoich sasiadów. Nie była to pierwsza próba strony polskiej wejścia w kooperację z którymś z państw demokracji ludowej ${ }^{22}$. Podobnie jak w latach 40., także i teraz strona czechosłowacka starała się dość ostrożnie odnosić do propozycji strony polskiej. W czasie spotkania Gomułki z Antoninem Novotným w Wysokich Tatrach w marcu 1963 r., pierwszy sekretarz Komunistycznej Partii Czechosłowacji kurtuazyjnie zapowiadał $\mathrm{z}$ jednej strony, iz „,w wielu dziedzinach istnieja jak najbardziej sprzyjające warunki dla wzajemnej korzystnej współpracy”, z drugiej jednak sugerował, iż strona czechosłowacka najpierw musi porozumieć się z Moskwa, bowiem to ZSRR zapewniało niemal 60\% czechosłowackich potrzeb surowcowych i było odbiorca 30\% czechosłowackiej produkcji eksportowej. W konkluzji zasugerował nawet uzależnienie losu polskich propozycji od trójstronnego porozumienia między Polska, ZSRR a Czechosłowacją. W notatce, która zachowała się z rozmów pierwszych sekretarzy odnotowano: „Na niektóre propozycje polskie, dotyczące tzw. «Porozumienia Producentów» Pierwszy Sekretarz

Republiki Czechosłowackiej, Warszawa, [15-18 IV 1959], bp. Strona czechosłowacka informowała, iż lada moment rozpocznie produkcję własnego samochodu osobowego o pojemności do $1000 \mathrm{~cm}^{3}$ i jakakolwiek współpraca byłaby możliwa dopiero po jej zakończeniu, które było planowane na początek lat 70.: tamże, MPC, sygn. 13/5, Notatka z rozmów grupy specjalistów PRL i CSRS w sprawach związanych z pogłębieniem współpracy w dziedzinie przemysłu samochodowego w generalnej perspektywie do 1980 roku, [9 VI 1961], bp.

${ }^{20}$ AAN, Komitet Centralny Polskiej Zjednoczonej Partii Robotniczej (dalej: KC PZPR), sygn. 237/XXXI-253, Notatka w sprawie rozszerzenie współpracy polsko-czechosłowackiej w zakresie wspólnej produkcji samochodów ciężarowych, autobusów i samochodów osobowych. Załącznik nr 3, [po 8 III 1963], k. 30-31.

${ }^{21}$ R. Skrzypek, dz. cyt., s. 223-227.

${ }^{22}$ Zob.: AAN, Komitet Centralny Polskiej Partii Robotniczej (dalej: KC PPR), sygn. 295/XI-393 ( $\mathrm{mf} 2354 / 5$ ), Stenogram z polskich przemówień w czasie partyjnej konferencji gospodarczej polsko-czechosłowackiej, odbytej w dniu 19 III 1948 r. w Pradze, k. $62-123$. 
KPCz nie udzielił konkretnych odpowiedzi. Dotyczyło do tych dziedzin przemysłu maszynowego, które powiązane sa z dostawami CSRS do Związku Radzieckiego" ${ }^{23}$.

Ustalenia dotyczące specjalizacji w produkcji przemysłowej wewnątrz RWPG zapadły podczas XVI sesji w 1962 r. W zakresie przemysłu maszynowego specjalizacją objęto 590 pozycji, zaś Polsce przypadły 162 rodzaje wyrobów, z tego samodzielnie wytwarzać miała 19 produktów, we współpracy z jednym krajem 63, dwoma 56, trzema 18 i czterema 6 . Największymi beneficjentami były ZSRR (387 wyrobów, z czego aż 132 samodzielnie) i NRD (odpowiednio 214 i 49). Polska wyprzedzała Czechosłowację (158 i 21). Jednocześnie jednak ustalenie listy produktów było dość trudnym zadaniem. Poszczególne kraje starały się o zakwalifikowanie do jak największej ilości przedsięwzięć, z tym że państwa będące na najwyższym stopniu rozwoju starały się, jak już wspomniano, nie dopuszczać innych do własnych technologii. Dotyczyło to przede wszystkim NRD oraz Czechosłowacji. Szczególnie agresywnie mieli postępować Niemcy, którzy uruchamiali u siebie produkcję nieprzewidzianą $\mathrm{w}$ ustaleniach specjalizacyjnych. Tak było w przypadku koparek, które wytwarzane miały być w Polsce i ZSRR. Dodatkowo zarówno Czechosłowacja, jak i NRD dążyły do zapewnienia sobie produkcji wyrobów szczególnie rentownych ${ }^{24}$.

O tym, iż strona polska bardzo poważnie była zainteresowana wspólna produkcją samochodów w ramach RWPG świadczy także poufny raport przygotowany w kwietniu $1963 \mathrm{r}$. przez Komisje Planowania przy Radzie Ministrów dla Biura Komitetu Wykonawczego RWPG ${ }^{25}$. Jednym z kierunków rozwoju gospodarczego PRL na najbliższe dwadzieścia lat miał być przemysł samochodowy wytwarzajacy dwa typy pojazdów

${ }^{23}$ AAN, KC PZPR, sygn. 237/XXXI-253, Notatka informacyjna o wynikach rozmów Pierwszego Sekretarza KC PZPR Towarzysza W. Gomułki z Pierwszym Sekretarzem KC KPCz Towarzyszem A. Novotným, które odbyły się w Wysokich Tatrach w dniach 14-15 marca 1963, k. 1-5.

${ }^{24}$ AAN, KC PZPR, sygn. 237/XXXI-342, Notatka dla Sekretarza KC tow. B. Jaszczuka w sprawie realizacji ustaleń specjalizacyjnych podjętych przez organa RWPG na lata 1962-1965, 12 II 1964, k. 2-8.

${ }_{25}$ Wcześniejszy o rok projekt montowni samochodów osobowych przygotowany przez Biuro Konstrukcyjne Przemysłu Motoryzacyjnego zakładał produkcję niewielkiej, siedmiuset kilowej osobówki o pojemności do $1000 \mathrm{~cm}^{3}$, mogącej pomieścić cztery osoby, rozwijającej maksymalną prędkość $120-140 \mathrm{~km} / \mathrm{h}$ oraz spalająca 6 -7 litrów paliwa na $100 \mathrm{~km}$. Koszt uruchomienia montowni, która byłaby w stanie wypuszczać rocznie 30 tys. pojazdów, szacowano na $200 \mathrm{mln}$ zł. W projekcie założono, iż część gotowych zespołów miała być importowana z Węgier; tamże, MPC, sygn. 43/16, Projekt wstępny montowni samochodów małolitrażowych, kwiecień 1962, bp. 
osobowych: średnio i małolitrażowy. Popularna osobówka o pojemności ok. $1000 \mathrm{~cm}^{3}$ miała być wytwarzana początkowo na Żeraniu, a w latach 70. już w nowej, specjalnie wybudowanej fabryce. Rozwinięcie tej gałęzi przemysłu maszynowego miało następnie skutkować kooperacją przy wytwarzaniu części i zespołów do wspólnie wytwarzanych samochodów osobowych i ciężarowych. Każdy z krajów biorących udział w tym wspólnym przedsięwzięciu miał posiadać własną montownię ${ }^{26}$. Jednak próby wcielania w życie tych planów okazały się nierealne wobec wzajemnej niechęci. Zmodernizowanie własnej produkcji także nie zabezpieczało planów eksportowych. Pozostawał zatem kierunek zachodni.

Jednym z głównych tematów obradującego w połowie czerwca 1964 r. IV Zjazdu PZPR był „kurs na zmianę struktury polskiego przemysłu". Władysław Gomułka we wprowadzajacym referacie zwracał uwagę na strukturę rodzimej produkcji przemysłowej, która na tle krajów gospodarczo rozwiniętych (NRD, Anglii) charakteryzowała się bardzo niskim wskaźnikiem dynamiki rozwoju przemysłu, przede wszystkim maszynowego. Zwiększenie produkcji tej gałęzi przemysłu miało dać pozytywny impuls także strukturze eksportu. W sprzedaży maszyn i urządzeń widziano bowiem „klucz otwierający drogę rozwojowi naszej gospodarki”. Dokonana miała zostać rekonstrukcja techniczna, zwłaszcza w przemyśle maszynowym i chemicznym ${ }^{27}$. Jak wiele było do zrobienia $\mathrm{w}$ tej kwestii pokazują zestawienia wartości eksportu i importu maszyn i urządzeń z lat 1956-1963. Rokrocznie wartość towarów tej grupy sprzedawanych za granicę była niższa niż wartość zakupów ${ }^{28}$.

${ }^{26}$ Tamże, KC PZPR, sygn. 1724 (mf 2892), Podstawowe kierunki rozwoju gospodarczego PRL w okresie 1961-1980, k. 267-268.

${ }^{27}$ IV Zjazd Polskiej Zjednoczonej Partii Robotniczej, 15-20 czerwca 1964 r., Warszawa 1964, s. 63-64, 110, 264.

${ }^{28}$ Tylko w 1963 r. polski eksport towarów wytwarzanych przez przemysł maszynowy był warty 2343,4 mln zł, podczas gdy import kształtował się na poziomie 2697,9 mln zł. W obu przypadkach wartość owych grup towarów stanowiła około 1/3 wartości całego handlu zagranicznego; Rocznik Statystyczny GUS 1965, Warszawa 1965, s. 335-336; por.: AAN, Ministerstwo Handlu Zagranicznego (dalej: MHZ), sygn. 19/3, Eksport z Polski maszyn, urządzeń i środków transportowych w latach 1949-1958 wg krajów sprzedaży, k. 23; tamże, Import do Polski maszyn, urządzeń i środków transportowych w latach 1949-1958 wg krajów sprzedaży, k. 24. Polska należała także do największych importerów wyrobów przemysłu maszynowego wewnątrz krajów należących do RWPG. W 1964 r. aż 42,7\% wartości całego polskiego importu z innych krajów bloku stanowiły maszyny i urządzenia: tamże, sygn. 2/5, Zmiany w strukturze towarowej obrotów we wzajemnej wymianie handlowej krajów członkowskich RWPG w okresie lat 1955-1964, bp. 
Kierunek zmian, który znalazł swój oddźwięk w końcowej uchwale IV zjazdu niejako potwierdzał tylko zapoczątkowane wcześniej działania. Już podczas X Plenum KC PZPR w przemyśle maszynowym widziano bazę do przyszłej „modernizacji i rekonstrukcji technicznej gospodarki narodowej" ${ }^{29}$. W lutym 1964 r. na posiedzeniu Biura Politycznego KC PZPR jego członkowie polecili opracować program rozwoju i rekonstrukcji przemysłu maszynowego, który miał być nastawiony na produkcję eksportowa. Zakładano, iż do roku 1970 będzie ona stanowić połowę eksportu ${ }^{30}$. Podstawą rekonstrukcji miały być przyjęte na tymże posiedzeniu Założenia rozwoju przemystu maszynowego w latach 1966-1970. Już pierwsze zdanie świadczyło o znaczącej zmianie podejścia. „Dla oceny osiagnięć i rozwoju przemysłu maszynowego nie wystarczaja już porównania $\mathrm{z}$ okresem przedwojennym i pierwszymi latami powojennymi”. Od tej pory punktem odniesienia miały stać się „tendencje rozwoju przemysłu maszynowego w krajach o rozwiniętym przemyśle". Dostrzeżono także braki w zakresie samochodów osobowych, gdzie „potrzeby [...] są większe niż możliwości produkcji” ${ }^{31}$. MPC obliczało, iż w samym tylko 1964 r. planowana produkcja syreny na poziomie 9,5 tys. sztuk będzie pokrywać zapotrzebowanie na ów pojazd jedynie w połowie. Przy stanie 175 tys. aut w 1963 r. jeden samochód osobowy przypadał na 175 osób, co stawiało Polskę na jednym z ostatnich miejsc w Europie. W Czechosłowacji był to jeden samochód na 78 osób, w NRD - 109, ale już we Włoszech czy Francji odpowiednio 20 i 8. Ambitny plan ministerstwa zakładał, że w 1970 r. jeden samochód osobowy przypadał będzie na 94 osoby. Aby to osiagnać, liczba aut musiała zostać podwojona. Przedstawiciele ministerstwa przygotowując Kierunki rozwoju do roku 1970, założyli, iż nakłady finansowe na rozwój branży motoryzacyjnej miały wynieść 5,3 mld zł w latach 1966-1970. Większość tej kwoty przypaść miała na rozbudowę zakładów produkujących samochody ciężarowe oraz ciagniki. Na rozwój produkcji samochodów osobowych zarezerwowano ok. $600 \mathrm{mln}$ zł. Część kwot miała zostać przeznaczona na zakup licencji na produkcję niektórych zespołów ${ }^{32}$.

${ }^{29}$ Przemówienie tow. Franciszka Waniotki wygłoszone na X Plenum KC PZPR 16 kwietnia 1962 r., w: X Plenum KC PZPR..., s. 5.

${ }^{30}$ AAN, KC PZPR, sygn. XIA-178, Protokół nr 96 posiedzenia Biura Politycznego w dniu 26 II 1964, k. 140-141.

31 Tamże, sygn. 1730 ( $\mathrm{mf}$ 2894), Założenia rozwoju przemysłu maszynowego w latach 1966-1970, Warszawa, 19 II 1964, k. 384, 390.

32 Tamże, Kierunki rozwoju przemysłu motoryzacyjnego. Ministerstwo Przemysłu Ciężkiego, k. 509, 512, 514. 
Na początku października 1964 r. na swoim kolejnym posiedzeniu Biuro Polityczne KC PZPR dało zielone światło do prowadzenia rozmów z potencjalnymi licencjodawcami. Punktem wyjścia była „słabość" Narodowego Planu Gospodarczego na rok 1965, zwłaszcza pod względem eksportu maszyn i urządzeń do krajów kapitalistycznych. W zgodnej opinii zebranych na posiedzeniu plan był „w wielu pozycjach napięty i nie odpowiada[ł] kierunkom rozwoju [...] nakreślonym przez IV Zjazd Partii”. W tej sytuacji należało postawić zwłaszcza na eksport. Biuro Polityczne wskazało podstawowe kierunki działań: opracowanie możliwości kooperacji z krajami kapitalistycznymi w zakresie rozwoju przemysłu eksportowego, zabezpieczenie środków na import elementów wstrzymujących produkcję eksportowa przemysłu maszynowego, przesunięcie najlepszych kadr technicznych do przemysłu produkującego na eksport oraz podjecie decyzji „w sprawie zakupu niezbędnych licencji zagranicznych” ${ }^{3}$. W MHZ zachowała się notatka świadcząca o nawiązaniu kontaktów z francuskim przemysłem motoryzacyjnym i firma Renault ${ }^{34}$, jednak najbardziej zaawansowane rozmowy strona polska prowadziła z włoskim Fiatem.

Historia polskich kontaktów z Fiatem sięgała jeszcze okresu międzywojennego. Pod koniec lat 20. powstała w Warszawie pierwsza montownia aut tej marki, zaś 21 września 1931 r. zawarta została umowa $\mathrm{z}$ włoskim gigantem motoryzacyjnym $\mathrm{w}$ sprawie produkcji w Warszawie samochodów osobowych fiat 508 i 518 ${ }^{35}$. Po zakończeniu II wojny światowej ponownie nawiązano kontakt z Fiatem, co zaowocowało podpisaniem umowy licencyjnej w kwietniu 1948 r. Rozpoczęta przy włoskiej pomocy budowę nowej fabryki samochodów osobowych na warszawskim Żeraniu dokończono jednak już w nowych realiach politycznych, zaś ostatecznie z taśm produkcyjnych jednej z czołowych inwestycji planu sześcioletniego zaczęły zjeżdżać budowane na licencji radzieckiej popularne warszawy ${ }^{36}$.

${ }^{33}$ Tamże, sygn. XIA-178, Protokół nr 4 posiedzenia Biura Politycznego w dn. 2 X 1964, k. 90.

${ }^{34}$ Tamże, MHZ, sygn. 35/26, Departament traktatów II, Warszawa, 28 VIII 1965, k. 137-138.

35 J. Tarczyński, T. Szczerbicki, Samochody osobowe Polski Fiat 508 i 518, Warszawa 2003, s. 10, 16-17; Rynek motoryzacyjny w Polsce, red. Z. Krasiński, Warszawa 1980, s. 41.

${ }^{36}$ Więcej na ten temat zob.: H. Wilk, „Nawet samochodów nie ma, zostały graty po Niemcach”- motoryzacyjny punkt startu - Polska 1944-1949, „Polska 1944/45-1989. Studia i Materiały", t. 12, 2014, s. 327-329. 
Ponowne nawiązanie kontaktów w latach sześćdziesiątych prawdopodobnie nie byłoby jednak możliwe, gdyby nie działajacca od $1954 \mathrm{r}$. w jugosłowiańskim Kragujevacu fabryka Zavodi Crvena Zastava, produkująca zastawę 600 będąca licencyjną wersją popularnej fiatowskiej „Sześćsetki” ${ }^{37}$. Włochy były bardzo ważnym partnerem handlowym Jugosławii już w latach 20. i 30. XX w. Wybuch II wojny światowej tylko na chwilę przerwał kontakty między dwoma krajami, zaś rozłam na linii Belgrad-Moskwa sprawił, że odnowienie interesów gospodarczych z krajami zachodnimi stało się sprawą niezmiernie ważna. Dość powiedzieć, iż kiedy tylko Jugosławia i Włochy uzgodniły porozumienie w kwestii przynależności Triestu, niemal natychmiast zaowocowało to podpisaniem umowy o współpracy ekonomicznej ${ }^{38}$. Kontrakt z włoską firmą został podpisany 12 kwietnia $1954 \mathrm{r}$. Fiat pozostawił w tyle oferty licencji innych firm włoskich, ale także francuskich, angielskich i amerykańskich ${ }^{39}$. Warto podkreślić, iż pierwsza połowa lat 50. była dla Fiata okresem światowej ekspansji: otwierano nowe fabryki w Ameryce Południowej i Środkowej (Argentynie, Brazylii, Meksyku i Wenezueli) oraz Europie (Hiszpania, Austria, RFN, Polska i ZSRR) ${ }^{40}$. Dla naszych rozważań bardzo istotny jest fakt, iż na początku lat 60. jednocześnie w fabrykach w Turynie i Kragujevacu rozpoczęła się produkcja fiatowskiego modelu 1300/1500. Specjaliści polscy bardzo wysoko ocenili ów model włoskiego samochodu - na tle swoich konkurentów wyróżniał się nowoczesnością konstrukcji, niskim ciężarem własnym, długim przebiegiem międzynaprawczym, małym zużyciem paliwa. Dla strony polskiej ważne były także: „technologiczność konstrukcji, a zatem możliwość uzyskania niskich kosztów wytwarzania”, dostęp

${ }^{37}$ M. Milijković, Western technology in socialist factory: the formative phase of the Yugoslav automobile industry, 1955-1962, Cold War History Research Center at Corvinas University of Budapest, 2013, s. 6 (http://www.etd.ceu.hu/2013/miljkovic_marko.pdf - dostęp: 18 V 2016). Pierwsze powojenne próby uruchomienia produkcji motoryzacyjnej w byłej fabryce zbrojeniowej w Kragujevcu miały miejsce na początku lat 50. Wówczas to Jugosławia rozpoczęła produkcję jeepów na mocy umowy z amerykańską firma, „Willys-Overland”. Po wyprodukowaniu pewnej liczby pojazdów umowa została zerwana ze względu na wygórowane żądania finansowe Amerykanów; tamże, s. 65.

38 J.A. Gierowski, Historia Wtoch, Wrocław-Warszawa-Kraków 1999, s. 556-557, 568-569; M. Milijković, dz. cyt., s. 6; T. Wituch, Spór o Triest-wczesny epizod „zimnej wojny”, „Dzieje Najnowsze” 1997, nr 2, s. 73-86.

${ }^{39}$ D. Turnock, The East European Economy in Context. Communism and Transition, London New York 1997, s. 32-33.

${ }^{40}$ M. Milijković, dz. cyt., s. 67; A. Władyka, Wszystko o... Fiat, Warszawa 1977, s. $27-30$. 
do zorganizowanego serwisu oraz potencjalnie wysokie zainteresowanie tym autem odbiorców na rynkach zbytu ${ }^{41}$.

Same zakłady „Czerwona Zastawa” także sprawiały bardzo dobre wrażenie. Kiedy pod koniec grudnia 1964 r. delegacja polskiego Ministerstwa Obrony Narodowej (MON) odwiedziła fabrykę w Kragujevacu, jej członkowie nie mogli wyjść z podziwu nad tym, co zastali na miejscu: „Zakład Czerwona Zastawa jest zakładem nowoczesnym, posiada nowoczesny park obrabiarkowo-maszynowy wyprodukowany w krajach kapitalistycznych. [...] Bardzo dobrze rozwiazany jest transport wewnętrzny, szczególnie dotyczy to linii montażowych", pisali w sprawozdaniu. Duże wrażenie robiła także wielkość produkcji: w 1964 r. fabrykę opuściło 34 tys. sztuk zastawy 750, zaś w 1970 r. planowano wytwarzać niemal pięć razy więcej samochodów różnych modeli ${ }^{42}$.

Gospodarcze kontakty pomiędzy Polską a Socjalistyczną Federacyjna Republika Jugosławii zostały nawiązane ponownie w drugiej połowie lat pięćdziesiątych. Wówczas to powołano do życia Polsko-Jugosłowiańską i Jugosłowiańsko-Polską Izby Handlowe, a następnie Polsko-Jugosłowiański Komitet Współpracy Gospodarczej ${ }^{43}$. O ile jeszcze w 1958 r. obroty handlowe pomiędzy oboma krajami wyniosły ok. 56 mln dolarów (Polska eksportowała towary na sumę 22,3 mln, zaś importowała na 24 mln dolarów), to w kolejnych latach rósł on systematycznie. W 1964 r. obroty wyniosły już niemal 100 mln dolarów, przy czym stosunek eksportu i importu kształtował się na poziomie 50,2 do 48,8 . Niewątpliwie niemal dwukrotny wzrost wartości wymiany handlowej pomiędzy oboma krajami był wynikiem podpisanej w grudniu 1960 r. wieloletniej umowy o dostawie towarów. Początkowo zakładano, iż łączny obrót towarowy w ciagu pięciu lat osiagnie 100 mln dolarów, jednak w kolejnych latach wskaźnik ten kilkakrotnie podnoszono. Polska sprzedawała Jugosławii: kompletne obiekty, silniki okrętowe, urzadzenia górnicze i hutnicze, obrabiarki, maszyny włókiennicze, koks, węgiel kamienny, surowce chemiczne i farmaceutyczne, tytoń, jaja, żywice. Natomiast w drugą stronę płynęły: silniki okrętowe, statki,

${ }^{41}$ AAN, KC PZPR, sygn. 1733 ( $\mathrm{mf} 2895$ ), Informacja o prowadzonych rozmowach w sprawie możliwości produkcji samochodów osobowych przy współpracy z Jugosławią, [10 XII 1964], k. 102.

${ }^{42}$ Tamże, Zjednoczenie Przemysłu Motoryzacyjnego (dalej:ZPM), sygn. 77/TK/1965, Wyciag ze sprawozdania z pobytu polskiej delegacji wojskowej w Jugosławii po linii Zarządu Technicznego Wojsk Pancernych Zjednoczenia Przemysłu Ciagnikowego i Służby Samochodowej MON, [styczeń 1965], bp; D. Turnock, dz. cyt., s. 33.

${ }^{43}$ A. Wieczorkiewicz, Polska - Jugostawia. Gospodarka - wspótpraca, Warszawa 1972, s. 97. 
urządzenia dla przemysłu spożywczego, rtęć, maszyny rolnicze, tlenek glinu, koncentraty cynku, magnezyty, ołów, wyroby przemysłu kablowego oraz metale kolorowe, tyton, wino, śliwki suszone ${ }^{44}$. Dodatkowym impulsem do zacieśnienia stosunków gospodarczych było podpisane w czerwcu 1964 r. porozumienie o współpracy przemysłowej ${ }^{45}$.

Pod koniec grudnia 1963 r. podczas rozmów Polsko-Jugosłowiańskiej Komisji Mieszanej do spraw Współpracy Przemysłowej, które miały miejsce w Belgradzie, delegacja jugosłowiańska po raz pierwszy wspomniała o możliwości podjęcia współpracy w zakresie przemysłu motoryzacyjnego i zaproponowała „rozważenie przez Polskę przyjęcia dokumentacji licencji produkcji samochodów fiat 1800 i 2300 wraz z pochodnymi”, jak również podjęcie kooperacji przy produkcji samochodów małolitrażowych produkowanych w Kragujevacu. Delegacja polska wówczas jeszcze nie podjęła tematu, zdecydowała się jednak na rozpoczęcie rozmów w sprawie importu większych ilości zastaw (5-6 tys. sztuk rocznie) w zamian za produkowane w Polsce urządzenia energetyczne. Umowa miała opiewać na sumę 30 mln dolarów ${ }^{46}$. Kolejne rozmowy w kwestii polsko-jugosłowiańskiej współpracy w zakresie przemysłu motoryzacyjnego miały miejsce we wrześniu 1964 r. Wówczas w Belgradzie bawiła polska delegacja MHZ i KWGzZ, której przewodził Stefan Jędrychowski. Na spotkaniach z jugosłowiańskimi przedstawicielami strona polska wyraziła chęć kontynuowania dotychczasowej współpracy oraz zaproponowała jej nowe kierunki. Wśród nich znalazły się m.in.: produkcja urządzeń do obiektów energetycznych, kolejnictwa, ciagników, maszyn budowlanych oraz samochodów osobowych. Przedstawiciele delegacji polskiej zachęcali, aby Jugosłowianie wystosowali oficjalna propozycję i sprecyzowali warunki współpracy w zakresie motoryzacji ${ }^{47}$. Tak też się stało. Jugosłowianie wstępnie zapowiedzieli przekazanie Polsce częściowej licencji na produkcję fiatowskiego modelu 1300/1500 (do czego upoważniał ich kontrakt z firmą włoska)

${ }_{44}$ Tamże; AAN, MHZ, sygn. 31/70, Materiały informacyjne i propozycje dla delegacji polskiej na spotkanie delegacji partyjno-rządowych Polski i Jugosławii, Warszawa, 20 VI 1964, bp.

${ }_{45}$ Tamże, Wspólne oświadczenie delegacji partyjno-rządowych Polskiej Rzeczypospolitej Ludowej i Socjalistycznej Federacyjnej Republiki Jugosławii (część gospodarcza), Warszawa, październik 1965, bp.

${ }_{46}$ Tamże, Urząd Rady Ministrów (dalej: URM), sygn. 72/37, Sprawozdanie delegacji polskiej Polsko-Jugosłowiańskiej Komisji Mieszanej ds. współpracy przemysłowej z rozmów przeprowadzonych na I spotkaniu w Belgradzie w dniach od 2 do 8 XII 1963, k. 238-239.

${ }_{47}$ Tamże, MHZ, sygn. 31/70, Notatka o konsultacji i rozmowach organów planowania PRL i SFRJ, odbytych w dniach 11-16 IX 1964 w Belgradzie. Poufne, bp. 
oraz pozytywnie wyrazili się o polskiej propozycji podziału wytwarzania elementów nowego samochodu. Polacy chcieli na przełomie lat 60 . i 70. dostarczać zakładom w Kragujevacu silniki i sprzęgła, zaś z Jugosławii otrzymywać elementy zawieszenia i tylne mosty. Jugosłowianie byli natomiast zainteresowani różnymi częściami karoserii oraz odlewami, które produkować miała strona polska.

Jednocześnie przedstawiciele Zjednoczenia Przemysłu Motoryzacyjnego rozpoczęli wstępne rozmowy z Fiatem, który wyraził zainteresowanie sprzedażą licencji. Pierwsze rozmowy odbyły się pod koniec października 1964 r. Kolejne zaś pod koniec grudnia. Wówczas delegacja polska spotkała się z dyrekcją włoskiej firmy. Od początku warunkiem, od którego uzależniano dalsze prowadzenie rozmów, było włączenie do kooperacji Jugosławii. Włosi stawiali tylko jeden warunek: w przypadku uzgodnienia trójstronnej współpracy należało dokonać podziału produkcji określonych zespołów pośród wszystkimi zainteresowanymi i ustalenie odpowiedniej jej wielkości. Poza tym Fiat gwarantował wszelką pomoc techniczna, materialną oraz szkoleniowa. Jednocześnie zapewniano stronę polska, iż nie będą czynione żadne trudności, jeśli licencja na nowy samochód zostanie przekazana bezpłatnie przez Jugosłowian. W takim przypadku rola Fiata zostałaby ograniczona głównie do wsparcia technicznego, zwłaszcza w początkowym okresie produkcji.

Sytuacja uległa zmianie po kolejnej turze rozmów ze stroną jugosłowiańską. Pewien rozdźwięk pojawił się już przy ustalaniu listy podzespołów, które miały być wytwarzane w fabrykach w obu krajach. Doszły do tego jeszcze bardzo ważne z punktu widzenia interesów polskiego eksportu kwestie sprzedaży zagranicznej. Jugosłowianie postawili warunek, iż Polska nie będzie mogła sprzedawać nowych samochodów do krajów, w których istniały lub miały powstać montownie jugosłowiańskie ${ }^{48}$. W ten sposób dość znacznie ograniczyłby się rynek zbytu polskich aut, a co było przecież jednym z kluczowych warunków strony polskiej. Fiat z kolei nie czynił takich przeszkód (oprócz eksportu do Włoch). Co więcej, zaoferował stronie polskiej pomoc w dystrybucji nowych samochodów wytwarzanych na Żeraniu poprzez sieć swoich przedstawicielstw na całym świecie ${ }^{49}$.

Kwestie licencji rozpatrzyło ponownie Biuro Polityczne, które na swoim posiedzeniu 16 lutego 1965 r. zaakceptowało przedstawiona koncepcję rozwoju przemysłu motoryzacyjnego oraz wyraziło zgodę

${ }_{48}$ Tamże, KC PZPR, sygn. 1733 (mf 2895), Notatka w sprawie uruchomienia w Polsce samochodu 1300/1500, warszawa, [10 II 1965], k. 117-118.

${ }^{49}$ Fiat $w$ Polsce (sprzedaz licencji), Warszawa 1980, s. 8-9. 
na rozpoczęcie rozmów z Fiatem przy jednoczesnym prowadzeniu dalszych negocjacji w sprawie możliwości podjęcia kooperacji z zakładami z Kragujevaca. Polecono przygotować dokładne wyliczenia kosztów w dwóch wypadkach: trójstronnej współpracy polsko-jugosłowiańsko-włoskiej oraz bez udziału partnera z Półwyspu Bałkańskiego. Dodatkowo zapadły wówczas także decyzje w sprawie przyszłości dotychczasowych samochodów wytwarzanych w FSO: produkcja syreny miała być podtrzymywana „w ilości nie wymagającej dodatkowych nakładów” na części zamienne i zakończyć się wraz z pojawieniem się fiatów. Kontynuowany miał być natomiast montaż różnych typów warszaw ${ }^{50}$.

Pertraktacje z Fiatem rozpoczęto w maju 1965 r. Wówczas to przebywająca w Warszawie włoska delegacja przekazała przedstawicielom Zjednoczenia Przemysłu Motoryzacyjnego kwestionariusz niezbędny do opracowania wstępnego projektu porozumienia licencyjnego. Dokument ten został następnie przygotowany i wysłany do Turynu w czerwcu $1965 r .{ }^{51} \mathrm{~W}$ toku negocjacji z Fiatem powoli odchodzono od kierunku jugosłowiańskiego. Oprócz wymienionych wcześniej przyczyn (ograniczenia $\mathrm{w}$ eksporcie, problemy w porozumieniu w kwestii produkcji poszczególnych części nowego auta) za Fiatem przemawiało także ogromne doświadczenie $\mathrm{w}$ prowadzeniu szkoleń oraz zaplecze technologiczne, które umożliwiało o wiele sprawniejsze przygotowanie planów i projektów dotyczących rozbudowy zakładów na Żeraniu. Nie bez znaczenia był także fakt, iż Fiat posiadał wiele patentów, których odstapienie Polsce, przy zawarciu umowy licencyjnej, było o wiele bardziej prawdopodobne ${ }^{52}$.

Oferta Fiata była zatem najkorzystniejsza. W pewnym stopniu o wyborze firmy $\mathrm{z}$ siedzibą w Turynie zadecydowały także historyczne kontakty, zarówno te z okresu II RP, jak i z końca lat 40. Andrzej Władyka, jeden z dyrektorów „Pol-Motu” tak podsumował podjętą decyzję: „Przyczyn było kilka. Fiat produkował nowoczesne i zarazem popularne samochody o małym i średnim litrażu. Posiadał bogate doświadczenie w dziedzinie przekazywania know-how i uruchamiania produkcji na

${ }^{50}$ AAN, KC PZPR, sygn. 1733 (mf 2895), Protokół nr 11 posiedzenia Biura Politycznego w dniu 16 II 1965, k. 80. Ostatecznie syrena produkowana była jednak jeszcze przez niemal 20 lat - do 1983 r., natomiast ostatnia warszawa zjechała z taśmy montażowej Żerania w marcu 1973 r.

${ }^{51}$ Tamże, MHZ, sygn. 59/3, Dotyczy: Współpracy z Fiatem, Warszawa, 29 VI 1965, bp.

${ }^{52}$ Tamże, KC PZPR, sygn. 1733 (mf 2895), Informacja o prowadzonych rozmowach w sprawie możliwości produkcji samochodów osobowych przy współpracy z Jugosławia, [10 XII 1964], k. 106. 
podstawie licencji i to nie tylko w krajach kapitalistycznych"53. Słowa Władyki potwierdzał Tadeusz Wrzaszczyk, wówczas dyrektor ZPM, i dodawał: „Zakup licencji wynikał przede wszystkim z konieczności szybkiego pokonania dystansu, dzielacego nasz przemysł samochodowy od jego przodujacych w świecie odpowiedników. Wnikliwa analiza wykazała, że rozwiązanie licencyjne jest tu w pełni ekonomiczne uzasadnione i rozwiązuje problem stosunkowo najszybciej przy największym stopniu pewności dobrych rezultatów. [...] Poza tym - wóz ten nam odpowiada, jest ekonomiczny w produkcji [...]"54.

Umowę podpisano ostatecznie 22 grudnia $1965 \mathrm{r}$. Zawarto ją pomiędzy firma Fiat a CHZPM „Motoimport”. 21 stycznia 1966 r. zatwierdził ją Komitet Ekonomiczny Rady Ministrów ${ }^{55}$. Warto odnotować, iż negocjacje były tajne, zaś wszelkie informacje na ten temat były kontrolowane przez cenzurę. Oficjalny komunikat o podpisaniu umowy pojawił się niemal rok po podpisaniu kontraktu ${ }^{56}$. Koszt zakupu licencji wyniósł 2,5 mln dolarów. Przy tworzeniu porozumienia dużą rolę odegrał Andrzej Górecki, późniejszy dyrektor „Pol-Motu”. Stronę włoska reprezentował m.in. Armando Fiorelli, który był jednym z organizatorów produkcji Fiata w międzywojennej Polsce ${ }^{57}$. Porozumienie zawierało wiele mniejszych kontraktów. Podstawowa licencja pozwalała na produkcję nowego modelu samochodu w Polsce. Fiat miał dostarczyć niezbędnej dokumentacji zakładów oraz specyfikację poszczególnych elementów. Jak już wspomniano wcześniej, włoska firma nie czyniła przeszkód, aby Polska eksportowała nowy samochód do wszystkich krajów, w tym także zrzeszonych w RWPG, jedynie z wyłączeniem Włoch. Warto zaznaczyć, iż takiej możliwości nie wynegocjował ZSRR dla produkowanej przez siebie łady. Wraz z zakupem licencji na samochód porozumiano się także w sprawie kredytowania zakupu urządzeń i oprzyrządowania, zaś spłata licencji mogła odbywać się poprzez zakupy dokonywane w Turynie. Przy pomocy włoskich specjalistów miała zostać także zmodernizowana żerańska FSO. Wyposażenie fabryki:

${ }^{53}$ A. Dłutek, dz. cyt., s. 6.

${ }_{54}$ Polski „Fiat”- kiedy i jaki?, „Motor” 1966, nr 47, s. 3.

55 AAN, MHZ, sygn. 14/21, Uchwała nr 14/66 Komitetu Ekonomicznego Rady Ministrów z dnia 21 I 1966 r. w sprawie zatwierdzenia umowy licencyjnej oraz współpracy technicznej z firmą, „Fiat”, k. 6.

${ }^{56}$ Archiwum Państwowe w Gdańsku (dalej: APG), Wojewódzki Urząd Kontroli Prasy, Publikacji i Widowisk w Gdańsku (dalej: WUPPiW Gdańsk), sygn. 318, Aktualne zapisy i zalecenia, 1966, k. 14 [za wskazanie źródła dziękuję Michałowi Przeperskiemu]; „Motoryzacja” 1966, nr 12, s. 1.

${ }^{57}$ Opowieść o FSO..., s. 73. 
maszyny, urządzenia do spawania i montażu w dużej mierze pochodziły od kooperantów Fiata z Wielkiej Brytanii, NRD, USA czy RFN, ale także i ZSRR. Kolejnym plusem była możliwość wykorzystywania zespołów i części nowego samochodu w innych pojazdach produkowanych w Polsce. Polski przemysł mógł także od tego momentu korzystać z kilkudziesięciu patentów będących własnością Fiata. Umowa weszła w życie w lutym 1966 r., zaś w kwietniu tego roku Rada Ministrów zatwierdziła podpisany w grudniu kontrakt. FSO została poddana gruntownej modernizacji, zaś produkcja warszawy została przeniesiona do hali przejętej od Warszawskich Zakładów Naprawy Samochodów, mieszczącej się przy ul. Stalingradzkiej. W tym samym miesiącu (kwiecień 1966) w Turynie rozpoczęło pracę biuro Motoimportu, do którego zadań należała koordynacja współpracy technicznej i handlowej między FSO a Fiatem. W drugiej połowie 1966 r. we Włoszech rozpoczęły się szkolenia polskich pracowników, zaś w kraju trwały prace związane $\mathrm{z}$ dostosowaniem włoskiej konstrukcji do polskich norm ${ }^{58}$.

Warto jeszcze wspomnieć o kooperacji polsko-jugosłowiańskiej. Pomimo odstapienia od pomysłu nabycia licencji od Jugosłowian oba kraje pozostały przy pomyśle współpracy przy wytwarzaniu zespołów do produkowanych u siebie aut. Podpisany 24 kwietnia 1966 r. kontrakt ramowy o wieloletniej współpracy technicznej zakładał wzajemne dostawy zespołów i części do produkcji samochodów 1300/1500 - tzw. standardów montażowych. Zakładano, iż w latach 1967-1975 obroty w dostawach do obu krajów miały wynieść około 144 mln dolarów i rozkładać się równo pomiędzy partnerów ${ }^{59}$. Umowa miała wejść w życie do końca listopada 1966 r., jednak w wyniku nieporozumień w kwestii ustalenia cen części będących przedmiotem kooperacji, udało się ją zatwierdzić dopiero 23 maja 1967 r. W lutym 1970 r. podpisano aneks zwiększajacy obustronne dostawy. Polska wysyłała do Jugosławii m.in. silniki, karoserie, zbiorniki paliwa, zaciski hamulców tarczowych, elementy zawieszenia i narzędzia kierownicy. W przeciwna stronę wędrowały: tylne mosty, nagrzewnice i chłodnice, rozruszniki, tłoki i sworznie, filtry olejowe i powietrza, wycieraczki i inne detale ${ }^{60}$.

${ }_{58}$ Tamże, s. 7; Z. Podbielski, Polski Fiat 125p/FSO 125p, Warszawa 2009, s. 24; Fiat $w$ Polsce (sprzedaz licencji)..., s. 8-9.

59 AAN, MHZ, sygn. 31/70, Projekt protokołu VIII Sesji Polsko-Jugosłowiańskiego Komitety Współpracy Gospodarczej, bp.; tamże, Dotyczy: sprawozdania Ambasady PRL w Belgradzie z dnia 17 III 1966 r. o realizacji polsko-jugosłowiańskiej współpracy gospodarczej, 14 VI 1966, bp.

${ }^{60}$ Z. Podbielski, dz. cyt., s. 52; B. Ryś, Rozwój polsko-jugosłowiańskich stosunków gospodarczych, Łódź 1986, s. 268-269. 
Ze sprzedawanych do Jugosławii części w Kragujevacu montowano samochód zastawa $1100 \mathrm{p}^{61}$. W tym samym roku strona polska zawarła umowę z ZSRR o wzajemnych dostawach części samochodowych ${ }^{62}$. Andrzej Krzysztof Wróblewski po latach pisał, iż Fiat stał się dla krajów socjalistycznych „drugim rurociagiem przyjaźni, bo połączył jednym kooperacyjnym łańcuchem różne kraje socjalistyczne, którym inaczej trudno było się dogadać"63.

Umowa grudniowa dotyczyła produkcji fiata 1300/1500, jednak już w maju 1966 r. podpisano aneks do umowy, na którego mocy nadwozie nowego samochodu montowanego w Polsce pochodzić miało od wciąż opracowywanego modelu 125. Sprzeciw wyrazić mieli pracownicy FSO, na wieść o tym, iż Fiat planował zakończenie (i faktycznie ją zakończył) produkcji tego modelu w roku 1967. Oznaczało to, iż w żerańskiej fabryce miał być produkowany samochód, który nie miał swojego odpowiednika nigdzie indziej - stąd też pojawienie się literki „p” przy numerze „125”64.

Pojawia się pytanie: dlaczego strona polska zdecydowała się kupić licencję na samochód, który już wówczas był uważany przez stronę włoską za przestarzały? Być może zadecydowała o tym jazda próbna, która modelem 125 na fabrycznym torze FSO odbył premier Józef Cyrankiewicz. Niestety, podczas przejazdu przez odcinek falisty pękła miska olejowa, co oznaczało, iż samochód może mieć problemy na wyboistych polskich drogach ${ }^{65}$. Prawdopodobnie jednak zadecydowały o tym nieco inne czynniki. Decydując się na wybór starszego modelu 1300/1500, poza wspomnianymi już zaletami eksploatacyjnymi, strona polska kierowała się kwestiami technologicznymi. Przygotowany w kwietniu 1965 r. przez Wydział Przemysłu Ciężkiego i Komunikacji KC PZPR raport o nowych konstrukcjach i prototypach, obejmujący także wyroby branży motoryzacyjnej, nie pozostawiał złudzeń co do możliwości tego przemysłu. Zwracano uwagę na niedostateczną jakość stosowanych surowców i materiałów hutniczych oraz osprzętu elektrotechnicznego. Autorzy raportu podkreślali, iż tyko poprawa jakości materiałów i podzespołów pozwoli na uzyskanie maksymalnych korzyści z planowanej

61 W. Bukowski, Samochody PRL-u, Łódź 2010, s. 19.

${ }^{62}$ Opowieść o FSO..., s. 71.

${ }^{63}$ A.K. Wróblewski, Polska na kótkach, Warszawa 1989, s. 17.

${ }^{64}$ Z. Podbielski, dz. cyt., s. 25.

${ }^{65}$ Inaczej mówiąc: skoro model nowszy, czyli 125, okazał się być mniej trwały od modelu starszego (czyli 1300/1500) postanowiono wykorzystać nadwozie modelu 125, a resztę - modelu 1300/1500, tworząc w ten sposób całkowicie nowy model, czyli 125p; Opowieść o FSO..., s. 74. 
licencji ${ }^{66}$. W tej sytuacji zachodziła obawa, iż przy polskich ograniczeniach i zaawansowanej konstrukcji silnika w modelu 125 osiagnięcie pożądanej jakości produkcji tego elementu może okazać się bardzo problematyczne i kosztowne ${ }^{67}$. Po drugie, wraz z licencją na model 1300/1500 Polska zakupiła wysłużoną linię produkcyjna silników do tego pojazdu, która była przez Włochów właśnie wycofywana z turyńskiej fabryki. Oceniano, iż w warunkach polskich będzie mogła być eksploatowana przez dekadę. Jak się później okazało, pracowała o połowę dłużej68.

Pierwszy egzemplarz nowego fiata 125 p o pojemności $1300 \mathrm{~cm}^{3}$ zjechał z żerańskiej linii montażowej 28 listopada 1967 r., a więc po 21 miesiącach od podpisania umowy licencyjnej. Był on zmontowany wyłącznie z części włoskich. Pół roku później fabrykę opuścił tysięczny egzemplarz, zaś do końca 1968 r. produkcja wyniosła ponad 7 tys. sztuk. Pierwsze samochody o wyższej pojemności $\left(1500 \mathrm{~cm}^{3}\right)$ pojawiły się w 1969 r. ${ }^{69}$ Ostateczny koszt uruchomienia produkcji popularnego „dużego fiata” wyniósł według różnych szacunków 30-40 mln dolarów ${ }^{70}$.

Do sprzedaży fiaty trafily w 1968 r. Wówczas to bank Pekao rozesłał do swoich klientów, którzy posiadali konta dewizowe, a na nich co najmniej 1 tys. dolarów, informację o możliwości zakupu w ramach eksportu wewnętrznego „samochodów osobowych marki «Fiat 125p» produkcji polskiej na licencji włoskiej”. Cena była dość wygórowana i wynosiła 2,3 tys. dolarów. Jak pisze Tomasz Szczerbicki, bardzo szybko cenę obniżono poniżej 2 tysięcy dolarów ${ }^{71}$. Uzyskane w ten sposób dewizy miały być przeznaczone na pokrycie kosztów importu kooperacyjnego z Włoch ${ }^{72}$.

Andrzej Krzysztof Wróblewski z właściwą sobie ironia pisał w „Polityce” o pierwszych „dolarowych” nabywcach polskich fiatów: „Szczęśliwcy! Kupili prawdziwy samochód, póki montowany z włoskich części. Dla nas zostanie krajowa włoszczyzna"73.

${ }^{66}$ AAN, KC PZPR, sygn. 237/IX/105, Informacja o wynikach przeglądu nowych konstrukcji i prototypów, kwiecień 1965, k. 65.

${ }^{67}$ Por.: St. Szelichowski, Jeździmy Polskim Fiatem 125P, „Motor” 1968, nr 15, s. 9.

68 Z. Podbielski, dz. cyt., s. 26-27; A. Dłutek, dz. cyt., s. 7.

69 Z. Podbielski, dz. cyt., s. 26.

70 Tadeusz Wrzaszczyk w wywiadzie udzielonym tygodnikowi „Motor” podawał wyższą kwotę: Opowieść o FSO..., S. 83; A. Dłutek, dz. cyt., s. 7.

${ }^{71}$ T. Szczerbicki, Samochody w PRL. Rzecz o motoryzacji i nie tylko..., Poznań 2011, s. 341.

${ }^{72}$ AAN, URM, sygn. 72/18, Notatka Zespołu Przemysłu Maszynowego z wykonania zaleceń grupy roboczej powołanej w maju 1966 r., ds. aktualizacji planu importu kooperacyjnego z KK w latach 1966-1970, k. 175-176.

${ }^{73}$ A.K. Wróblewski, Fiat bez kompromisów, „Polityka” 1968, nr 13 (30 III 1968), s. 3. 
Początkowo eksport nowych fiatów był kierowany do najbliższych sąiadów: Czechosłowacji, NRD oraz Węgier. Wówczas także nastapiła reorganizacja eksportu wyrobów przemysłu motoryzacyjnego. W marcu 1968 r. w miejsce CHZ „Motoimportu” powołano Przedsiębiorstwo Handlu Zagranicznego Przemysłu Motoryzacyjnego „Polmo”, które zamiast MHZ podporządkowano poprzez ZPM Ministerstwu Przemysłu Maszynowego (MPM) ${ }^{74}$. Miesiąc później nazwę nowo powstałej jednostki zmieniono na „Pol-Mot”75. Od 1970 r. postanowiono rozszerzyć zakres importu i duże fiaty trafiły do Europy Zachodniej: Holandii, Austrii, Grecji i Finlandii. W przypadku eksportu do Niderlandów strona polska podpisała umowę z najstarszym holenderskim importerem samochodów produkowanych przez Fiata - firmą Lang. Z kolei dla importu do Finlandii powołano specjalną spółkę Autola OY, na której czele stanął znany fiński rajdowiec Pauli Toivonen ${ }^{76}$. W latach kolejnych duże fiaty pojawiły się także na drogach: Francji, RFN, Belgii, Danii, Szwecji, Norwegii oraz krajów azjatyckich (Irak, Chiny, Tajlandia, Japonia), afrykańskich (Algieria, Ghana, Liberia) oraz amerykańskich (głównie Ameryki Łacińskiej i Południowej, choć kilkanaście egzemplarzy sprzedano do USA). W ciagu niemal ćwierćwiecza produkcji produkowane w FSO samochody trafiły do przeszło 80 krajów na całym świecie, w tym do tak egzotycznych, jak Mali, Gwinea czy Fidżi. Spośród państw socjalistycznych fiaty 125 p kierowano przede wszystkim do Jugosławii (115 tys. sztuk), Czechosłowacji (82 tys. sztuk), Węgier (67 tys. sztuk) oraz Bułgarii (46 tys. sztuk) i NRD (43 tys. sztuk.). Co ciekawe, spośród krajów kapitalistycznych największymi odbiorcami były Anglia, gdzie sprzedano niemal 50 tys. sztuk, oraz Francja ${ }^{77}$ (27 tys. szt.). Łacznie na rynek polski oraz zagraniczny trafiło ponad 586 tys. egzemplarzy fiata 125p. Jeśli jednak uwzględnione zostaną także wspomniane wcześniej standardy montażowe, to wówczas wielkość ta wzrośnie do 874 tys.

${ }^{74}$ AAN, MPM, sygn. 21/2, Zarządzenie nr 21/Org/68 Ministra Przemysłu Maszynowego z dnia 18 III 1968 w sprawie utworzenia przedsiębiorstwa państwowego pod nazwą: Przedsiębiorstwo Handlu Zagranicznego Przemysłu Motoryzacyjnego „Polmo”, k. $1-2$.

75 Tamże, Zarządzenie nr 30/Org/68 Ministra Przemysłu Maszynowego z dnia 23 IV 1968 w sprawie zmiany nazwy przedsiębiorstwa państwowego: Przedsiębiorstwo Handlu Zagranicznego Przemysłu Motoryzacyjnego „Polmo” z siedzibą w Warszawie, k. 3.

${ }^{76}$ R. Przybylski, Eksportowy hit PRL, „Rzeczpospolita”, 27 XI 2007.

77 Jeden odcinków Kroniki Filmowej z 1972 r. poświęcony był w całości paryskiemu punktowi sprzedaży fiata 125p należącego do włoskiej sieci Autobianchi przy Avenue Kléber, prowadzonemu przez „monsieur Chardonnet”. Znajdowała się tam także stacja obsługi i konserwacji: Polski Fiat w Paryżu, Polska Kronika Filmowa, 72/39B (http://www.kronikarp.pl/szukaj,32512,strona-1 - dostęp: 25 V 2016). 
Dość spora jak na ówczesne warunki sprzedaż eksportowa wymuszała szybką modernizację konstrukcji samochodu. Chciano w ten sposób sprostać rosnacym wymaganiom zagranicznych odbiorców, zwłaszcza zachodnich $^{78}$. Z tego też powodu eksportowe egzemplarze auta były bardzo poszukiwane wśród polskich nabywców ${ }^{79}$.

Niemal od samego początku decyzja o licencji na model średniolitrażowy poddana była krytyce ze strony środowisk opowiadających się za produkcją małolitrażowej osobówki, która miała zmotoryzować polskie społeczeństwo. Przodowali w tym zwłaszcza członkowie Rady Motoryzacyjnej, którzy na swoich posiedzeniach raz po raz „ścierali się” z przedstawicielami rządu w sprawie obranej przez nich ścieżki rozwoju. W maju 1965 r., a więc w momencie rozpoczęcia polsko-włoskich pertraktacji w sprawie licencji, przedstawiciele rady przygotowali projekt uchwały, w której oceniali zamierzenia rozwojowe przemysłu motoryzacyjnego w latach 1966-1970. Skrytykowano w niej brak jakichkolwiek zamierzeń odnośnie do produkcji samochodów małolitrażowych oraz ciagłe odkładanie rozpoczęcia produkcji zmodernizowanych syreny i warszawy. Na krytykę odpowiedział wiceminister Józef Talma, który zdradził zamierzenia rządu odnośnie do zakupu licencji na model 1300/1500, sugerując jednocześnie, iż umieszczanie w uchwale informacji o potrzebach $\mathrm{w}$ zakresie samochodów małolitrażowych mogło zaszkodzić prowadzonym rozmowom. Informacja ta nie przypadła do gustu zebranym, którzy, głosem Aleksandra Rostockiego, dość mocno skrytykowali postawę rządu: „Na podstawie swoich 20-letnich obserwacji - mówił Rostocki - do tej pory nie było odpowiedniego momentu statystycznego do przyjęcia wiążących wytycznych rozwoju przemysłu

${ }^{78}$ Przykładowo w 1972 r. podjęto decyzje w sprawie zakupu szeregu patentów, na łączną sumę ponad 900 tys. zł, decydujących o bezpieczeństwie i komforcie jazdy, które były wymagane przepisami ECE (United Nations Economic Commission for Europe, Europejska Komisja Gospodarcza - organ ONZ powołany w 1947 r., zajmujacy się ustalaniem norm obowiązujących na terenie państw należących do Europejskiej Wspólnoty Gospodarczej, w tym także bezpieczeństwa drogowego) tudzież względami konkurencji. Wśród dziesięciu patentów, które miały zostać zakupione, znalazły się m.in.: szyba tylna ogrzewana (do tej pory montowano ja jedynie w egzemplarzach fiata 125p, który był eksportowany do Szwajcarii), pompa elektryczna spryskiwacza szyb oraz sygnalizacja uszkodzenia układu hamulcowego (przewidywano, iż oba elementy wyposażenia będą wymagane przez większość krajów Europy Zachodniej od 1973 r.); AAN, ZPM, sygn. 0519/72, Wniosek ostateczny Fabryki Samochodów Osobowych o podjęcie decyzji w sprawie zakupu patentów dotyczących elementów wyposażenia samochodu licencyjnego FIAT $125 \mathrm{P}$, związanych z jego modernizacją wg wymagań przepisów ECE w zakresie bezpieczeństwa i komfortu jazdy, Warszawa, 22 V 1972, bp.

79 Z. Podbielski, dz. cyt., s. 52-55; Opowieść o FSO..., s. 159. 
motoryzacyjnego [w sprawie samochodów osobowych]. Przemysł ten ciagle znajduje się w sferze projektów i dyskusji. [...] Dzisiejsza dyskusja wnosi akcent pesymistyczny, że w latach następnych również takiego momentu statystycznego nie będzie się można spodziewać"80. Warto zauważyć, iż zwolennicy rozwoju produkcji samochodów osobowych zyskali dość niespodziewanego, lecz potężnego sojusznika. Zmiana na Kremlu i zastapienie Nikity Chruszczowa Leonidem Breżniewem w Związku Radzieckim przyniosła zwrot o 180 stopni także w tym zakresie. Przeciwny rozwojowi motoryzacji indywidualnej i stawiający na rozwój transportu zbiorowego Chruszczow został odsunięty ze stanowiska pierwszego sekretarza i premiera rządu ZSRR. Aleksiej Kosygin, który obją funkcję premiera, podobnie zresztą jak Breżniew, był pasjonatem motoryzacji. Ten pierwszy miał powiedzieć nawet: „wiecie, z jakim uporem narzucano ideę, że w naszym kraju nie ma potrzeb szerokiego rozwoju produkcji samochodów osobowych. Jak gdyby wszyscy ludzie powinni jeździć tylko autobusami”"1. Efektem działań nowej ekipy na Kremlu był m.in. kontrakt z Fiatem ${ }^{82}$.

Wracając jednak na grunt polski, warto zauważyć, iż zmiany $\mathrm{u}$ wschodniego sasiada nie zmieniły postawy rządzących w Warszawie. Niezmienna była także jej krytyka. Po raz kolejny Talma musiał bronić decyzji o podpisaniu licencji na samochód średniolitrażowy przed członkami Rady Motoryzacyjnej. Tym razem jego wypowiedź miała charakter głosu dość drastycznie ucinającego dalszą dyskusję: „nie wszystkie opinie Rady Motoryzacyjnej zostały uwzględnione w decyzjach rzadowych, które jednoznacznie określiły kierunki rozwoju przemysłu motoryzacyjnego. Powracanie więc do rozważań na temat konstrukcji, które nie wejdą do produkcji jest niecelowe i może być szkodliwe. [...] Program asortymentowy produkcji był uzgodniony ze wszystkimi resortami na szczeblu wyższym przy przyjęciu słusznej zasady, że nie wszystkie asortymenty będą produkowane w kraju. W tym trybie

${ }^{80}$ AAN, MK, sygn. II/2, Protokół nr 3/65 z Posiedzenia Prezydium Rady Motoryzacyjnej odbytego w dniu 7 V 1965, k. 628-630v.

${ }^{81}$ Radziecka motoryzacja w ofensywie, „Motoryzacja” 1965, nr 11, s. 236.

${ }^{82} \mathrm{Kreml}$ dość skrupulatnie przygotował się do podpisania kontraktu licencyjnego. Początkowo, oprócz Fiata, brano pod uwage jeszcze firmy niemieckie (Volkswagen) i francuskie (Renault). Ostatecznie zdecydowano się na rozwiązanie włoskie i model 124, który zajął pierwsze miejsce w prestiżowym konkursie na Europejski Samochód Roku 1967. Umowa została podpisana 4 V 1966 r. i opiewała na sumę $900 \mathrm{mln}$ dolarów. Jak głosi plotka, jako pierwszy nowe auto testował Leonid Breżniew, który w specjalnie dla niego sprowadzonej „sto dwudziestce czwórce” zrobił testowe okrażenie Kremla; L.H. Siegelbaum, Cars for Comrades. The Life of Soviet Automobile, Cornell University Press 2008, s. 91-92. 
również została podjęta po szerokich dyskusjach decyzja o produkcji samochodu osobowego 1300-1500 [c]m ${ }^{3 " 83}$.

$\mathrm{Z}$ cała pewnościa fiat $125 \mathrm{p}$ nie mógł być samochodem, który miał zmotoryzować polskie społeczeństwo, tym bardziej że nie planowano, aby takim autem się stał. Badania przeprowadzone przez poznańskich socjologów na początku lat 70. potwierdzaja tą tezę. Jak się bowiem okazało, duży fiat rzadko był „pierwszym wyborem” dla rozpoczynajacych przygodę z motoryzacja. $\mathrm{O}$ wiele popularniejsze były tańsze modele i marki (syrena, trabant, zastawa). Fiat 125p z kolei o wiele częściej był wybierany przez osoby, które już wcześniej posiadały samochody ${ }^{84}$.

O produkcji modelu 125p zadecydowały przede wszystkim względy eksportowe i możliwość ściagnięcia w ten sposób do kraju dewiz. Jak się później okazało, możliwość wykorzystana. Rok 1968 był momentem, kiedy eksport produkowanych na Żeraniu warszaw był najwyższy w historii i osiagnał 8888 sztuk (na 17780 wyprodukowanych). W tym samym roku wyeksportowano 1876 fiatów 125p (na 7101 wyprodukowanych). W latach kolejnych produkcja i eksport dużych fiatów rosły, zaś warszaw spadały, co było związane z zakończeniem produkcji tego auta w 1973 r. W przypadku dużego fiata obie wartości osiągnęły swoje maksymalne poziomy w połowie następnej dekady. Wówczas, w latach 1975-1976 wyprodukowano odpowiednio 114327 i 116940, zaś na eksport skierowano odpowiednio: 82909 i 83413 samochodów ${ }^{85}$.

Skuteczność podjętych w pierwszej połowie lat 60. działań zmierzających w kierunku zmodernizowania polskiego przemysłu maszynowego należy także ocenić częściowo pozytywnie. Wpływ licencji z 1965 r. na modernizację przemysłu był niewatpliwy, zaś dokonany wówczas skok jakościowy położył podwaliny pod boom motoryzacyjny lat 70. Cytowany już A.K. Wróblewski pisał o Żeraniu z początku lat 60. w sposób

${ }^{83}$ AAN, MK, sygn. II/2, Protokół nr 1/66 z posiedzenia Prezydium Rady Motoryzacyjnej, odbytego w dniu 16 II 1966, k. 659. Na przedzjazdowej konferencji wojewódzkiej KW PZPR w Katowicach, która odbyła się na początku października 1968 r., Ryszard Dziopak, dyrektor Wytwórni Sprzętu Mechanicznego w Bielsku-Białej mówił tak: „W samochodach osobowych nawet maksymalna produkcja nowouruchomionego «Fiata 125P» nie zaspokoi naszych potrzeb i nie rozwiąże potrzeb rynku. Wydaje mi się, że zupełnie błędne jest uciekanie niektórych kierowników naszego życia gospodarczego od tego problemu, przyznaję, od problemu trudnego", tamże, KC PZPR, sygn. 237/VII-5418, Protokół z przedzjazdowej konferencji wojewódzkiej KW PZPR w Katowicach odbytej w dniu 7-8 X 1968, k. 74.

${ }^{84}$ Z. Krasiński, Czynniki ekonomiczno-społeczne rozwoju motoryzacji indywidualnej $w$ Polsce $w$ świetle badań ankietowych, Poznań 1972, s. 98.

${ }^{85}$ Opowieść o FSO..., s. 156-158; Rynek motoryzacyjny w Polsce, red. Zdzisław Krasiński, Warszawa 1980, s. 48-49. 
następujący: „Dwa lata temu nie było jeszcze żadnych zmian widocznych gołym okiem. FSO wyglądała jak dawniej i jej reputacja wygladała jak dawniej. Zdjęty garb z tyłu warszawy i nowy lakier były jedynymi poważniejszymi osiągnięciami fabryki, która może nie umiała, ale przede wszystkim nie mogła zrobić niczego poważniejszego"86. Teraz rzeczywistość praskiej fabryki, jak i całego przemysłu motoryzacyjnego miała się zmienić. Produkcja fiata 125p opierała się na kooperacji, w której udział wziać miało ostatecznie ponad 150 zakładów różnych branż, a które dostarczać miały podzespoły i części do nowego auta ${ }^{87}$. Dla polskiego przemysłu motoryzacyjnego była to z cała pewnościa ogromna i dość bolesna zmiana. Władysław Staniszewski z FSO przekonywał, iż problem w trudnym przebiegu zmian modernizacyjnych był związany z trudnościami, jakie polski przemysł napotykał przy próbie spełnienia wymagań w zakresie środków produkcji, które „pozwoliłyby na wprowadzenie postępu technicznego na poziomie europejskim" ${ }^{8}$. Jednocześnie jednak cała polityka określana jako „polityka selektywnego wzrostu", a której to modernizacja przemysłu motoryzacyjnego była częścia, okazała się tylko pogłębić chaos istniejący w gospodarce polskiej ${ }^{89}$. Rozwój produkcji eksportowej kosztem branż wykonujacych dobra konsumpcyjne (czego znakomitym przykładem jest choćby zaniedbanie poprzez produkcje fiata $125 \mathrm{p}$ rozwoju motoryzacji osobowej opartego na małych samochodach) pogłębiał istniejące problemy ${ }^{90}$. Co więcej, wytworzyły się bardzo istotne różnice w poziomie jakościowym pomiędzy artykułami produkowanymi na eksport i na rynek wewnętrzny (tutaj także duży fiat może służyć za przykład).

\section{Bibliografia}

III Zjazd Polskiej Zjednoczonej Partii Robotniczej. Stenogram. Warszawa 10 III-19 III 1959 r., Warszawa 1959.

IV Zjazd Polskiej Zjednoczonej Partii Robotniczej, 15-20 czerwca 1964 r., Warszawa 1964.

${ }^{86}$ A.K. Wróblewski, Fiat bez kompromisów..., s. 3.

87 Opowieść o FSO..., s. 77 i nn.

88 AAN, KC PZPR, sygn. 237/III-57, Stenogram z IV Plenarnego posiedzenia Komitetu Centralnego Polskiej Zjednoczonej Partii Robotniczej w dniach 14 i 15 XI 1969, k. 41.

${ }^{89}$ Por.: J.Skodlarski, Zarys historiigospodarczej Polski, Warszawa 2007, s. 432-433.

90 A. Zawistowski, Polska Ludowa. Wzrost podporzadkowany doktrynie socjalistycznej, w: Polskie osiagnięcia gospodarcze, red. J. Kaliński, Warszawa 2010, s. 202-203. 
X Plenum Komitetu Centralnego Polskiej Zjednoczonej Partii Robotniczej w dniach 16-18 IV 1962 r., Warszawa 1962.

Bukowski W., Samochody PRL-u, Łódź 2010.

Dłutek A., Kooperacja polsko-włoska Fiat 126 - zakup licencji, Warszawa 1979.

Dwilewicz Ł., Reformy Bolesława Jaszczuka i polityka gospodarcza ekipy gierkowskiej - zwrot i ciagtość, w: Dekada Gierka. Wnioski do obecnego okresu modernizacji Polski, Warszawa 2011.

Fiat $w$ Polsce (sprzedaz licencji), Warszawa 1980.

Gierowski J.K., Historia Wtoch, Wrocław-Warszawa-Kraków 1999.

Kaliński J., Gospodarka Polski w latach 1944-1989. Przemiany strukturalne, Warszawa 1995.

Krasiński Z, Czynniki ekonomiczno-społeczne rozwoju motoryzacji indywidualnej $w$ Polsce $w$ świetle badań ankietowych, Poznań 1972.

Milijković M., Western technology in socialist factory: the formative phase of the Yugoslav automobile industry, 1955-1962, Cold War History Research Center at Corvinas University of Budapest, 2013.

Opowieść o FSO. Historia tej warszawskiej fabryki, red. prow. i koncepcja całości Z. Boniecki, przy współpr. R. Gajewskiego, Warszawa 2010.

Podbielski Z., Polski Fiat 125p/FSO 125p, Warszawa 2009.

Rynek motoryzacyjny w Polsce, red. Z. Krasiński, Warszawa 1980.

Ryś B., Rozwój polsko-jugostowiańskich stosunków gospodarczych, Łódź 1986.

Siegelbaum L.H., Cars for Comrades. The Life of Soviet Automobile, Cornell University Press 2008.

Skobelski R., Polityka PRL wobec panstw socjalistycznych w latach 1956-1970. Wspótpraca napięcia konflikty, Poznań 2010.

Skodlarski J., Zarys historii gospodarczej Polski, Warszawa 2007.

Szczerbicki T., Samochody PRL-u. Rzecz o motoryzacji i nie tylko..., Poznań 2011.

Tarczyński J., Szczerbicki T, Samochody osobowe Polski Fiat 508 i 518, Warszawa 2003.

Turnock D., The East European Economy in Context. Communism and Transition, London-New York 1997.

Wieczorkiewicz A., Polska - Jugostawia. Gospodarka, wspótpraca, Warszawa 1972.

Wilk H., „Nawet samochodów nie ma, zostały graty po Niemcach” - motoryzacyjny punkt startu - Polska 1944-1949, „Polska 1944/45-1989. Studia i Materiały", t. 12, 2014.

Wilk H., Samochód dla Towarzysza Wiestawa. Dyskusje nad kierunkiem rozwoju motoryzacji indywidualnej $w$ Polsce 1955-1970, „Polska 1944/451989. Studia i Materiały", t. 13, 2013.

Wituch T., Spór o Triest - wczesny epizod „zimnej wojny”, „Dzieje Najnowsze” 1997, nr 2.

Wróblewski A.K., Polska na kótkach, Warszawa 1989.

Zabłocki J., Dzienniki 1956-1965, t. 1, Warszawa 2008.

Zawistowski A., Polska Ludowa. Wzrost podporzqdkowany doktrynie socjalistycznej, w: Polskie osiagnięcia gospodarcze, red. J. Kaliński, Warszawa 2010. 
Hubert Wilk

Attempts of modernising the Polish machine industry in the second half of the 1960s. The case of Fiat 125p

(Summary)

In the 1960s the Polish machine industry manufactured cost-consuming car models with obsolete design. Despite its numerous drawbacks, the make Warszawa, produced in the Żerań district of Warsaw since 1951, was an important element of the Polish export. Nonetheless, the cost of the undertaking started to grow disproportionately at the beginning of the 1960s. Some proposed to remedy such state of affairs by manufacturing a new type of car in a joint effort with other countries of the Eastern Bloc. Poland initially attempted to engage in cooperation within the Council for Mutual Economic Assistance but in view of the reluctant stance of Czechoslovakia and East Germany, the country initiated talks with Yugoslavia, where the factory Crvena Zastava, open until 1954, manufactured popular cars under a license agreement with Italian Fiat. The negotiations did not render satisfying results and Poland eventually decided to seek to buy license for the production of Fiat 1300/1500 from the Turin-based company. The agreement with Fiat and the manufacture of a new car - Fiat $125 \mathrm{p}$ - positively influenced the structure of the export sector of the Polish machine industry. Nonetheless, the decision to sign the contract for the production of a car with mid-sized engine was criticised by automotive experts, who saw it as a wasted opportunity of developing a Polish car industry based on a compact car with small-sized engine.

Hubert Wilk - doktor nauk humanistycznych, adiunkt w Pracowni Badań nad Dziejami Polski po 1945 r. Instytutu Historii im. Tadeusza Manteuffla PAN w Warszawie; członek redakcji czasopisma „Świętokrzyskie Studia Archiwalno-Historyczne” oraz sekretarz redakcji „Polska 1944/45-1989. Studia i Materiały”; publikował m.in. w „Dziejach Najnowszych”, „Rocznikach Dziejów Społecznych i Gospodarczych”, „Kwartalniku Historycznym”, „Polska 1944/451989. Studia i Materiały”, „Polityce”, „Mówią Wieki” i „Pamięć.pl”; współpracuje z Muzeum Historii Polski i portalem www.polishhistory.org. E-mail: wilk.hubert@gmail.com. 